\author{
Olga Ivanova \\ 1a Inzhenernyi Ln., Kharkiv, Ukraine, laptevaou@gmail.com \\ Viacheslav Laptiev \\ Simon Kuznets Kharkiv National University of Economics \\ 9a Nauky Ave., Kharkiv, Ukraine, vlaptev777@gmail.com
}

Research Center for Industrial Problems of Development of the National Academy of Sciences of Ukraine,

\title{
TAX INCENTIVES FOR INNOVATION IN THE ENERGY SECTOR
}

\begin{abstract}
The article considers the current issues of stimulating innovation in the energy sector and rational use of energy resources. A three-level system of problem-oriented management of human resources for stimulating innovation in the energy sector is proposed. The system considers the impact of the human factor on innovative development at the national, regional and enterprise levels. Also, the need to encourage enterprises to hire highly qualified specialists in the sphere of energy saving and energy efficiency is proven. The role of the tax policy in state regulation of the rational use of energy resources and stimulation of innovation in the energy sector is substantiated. The tax incentives for the rational use of energy resources applied in the world practice are grouped. Features of the application of tax incentives (accelerated depreciation, tax credits, tax holidays, and tax reduction) for energy efficiency and energy saving of households and business entities are analyzed. Directions for stimulating innovation in the energy sector for the efficient use of energy resources are offered.
\end{abstract}

\section{Key words}

stimulation of innovation, tax incentives, state regulation, energy sector, energy efficiency, human resources

\section{Introduction}

Innovation is a force for progress in any sphere of human activity. Innovative development is an important factor for increasing the level of competitiveness of the country's national economy, its territorial units and business entities. Intensive development of international cooperation in the context of integration puts forward demands for the state's stimulation of innovative development in all spheres of the economy and creation of conditions for conducting innovative activity. An important role in this process is assigned to human resources, which, on the one hand, provide legislative and organizational mechanisms for stimulating innovation at the national and regional levels, and, on the other, ensure the development and implementation of new ideas and technologies. One of the sectors in which innovation is the key to increasing the competitiveness of the national economy and the standard of living of the population is the energy sector. Socio-economic development of the national economy under conditions of shortages of energy resources is impossible without development and implementation of a balanced state policy of stimulating the rational use of energy resources and innovations in the spheres of energy saving and energy efficiency. The development of directions for the rational use of energy resources stimulates the increase of financial stability, energy and environmental security, and, as a result, ensures the country's economic security and increases its competitiveness.

Research of problems in state regulation of the rational use of energy resources has been carried out by such scientists as L. Bretschger, V. Mykitenko, L. Petkova, D. Palamarchuk, H. Sanders, K. Hassett, M. Filippini, H. Hunt and I. Sotnik. Tax issues in the implementation of resource-saving measures have been investigated by A. Amosha, S. Aptekar and Y. Ivanov. Research in the field of energy efficiency of the economy has been engaged V. Zhovtyansky, M. Kulik, A. Sukhodolya, J. William, etc. The role of human resources in innovative development has been considered in the scientific works and research of D. Bell, M. Blaug, P. Burd'e, I. Kamenev, A. Korickij, Ju. Korchagin, B. Milner, V. Sinov, etc. However, the potential for innovation in the sphere of energy efficiency and energy saving is enormous and requires effective mechanisms of state support. Issues of the duality of the human factor in the process of applying tax incentives for innovative development, including in the energy sector, require further research. 
The human factor and state stimulation of innovative development

Specialists in the sphere of energy saving determine the state policy in this area as "the process of implementing particular actions by state authorities with the aim of influencing the national economy in order to ensure efficient and rational use of fuel and energy resources" [1]; "a system of purposeful actions by government departments with a view to formulating mechanisms of public administration to influence the national economy in order to ensure efficient and rational use of fuel and energy resources" [2]; "an organized and purposeful activity or inactivity of government departments to regulate the use of primary energy and its transformation in the national economy" [3]. The last definition more fully reflects the essence of this concept but does not focus on mechanisms that stimulate the rational use of energy resources, which is also a subject to regulate.

State regulation of the rational use of energy resources and energy innovation should be viewed as a process of targeted influence (stimulation, support) by the state with the help of instruments (tax, budgetary, monetary, etc.) (Figure 1) [4] through the system of bodies authorized by them on tax subjects with the purpose of their rational use of energy resources.

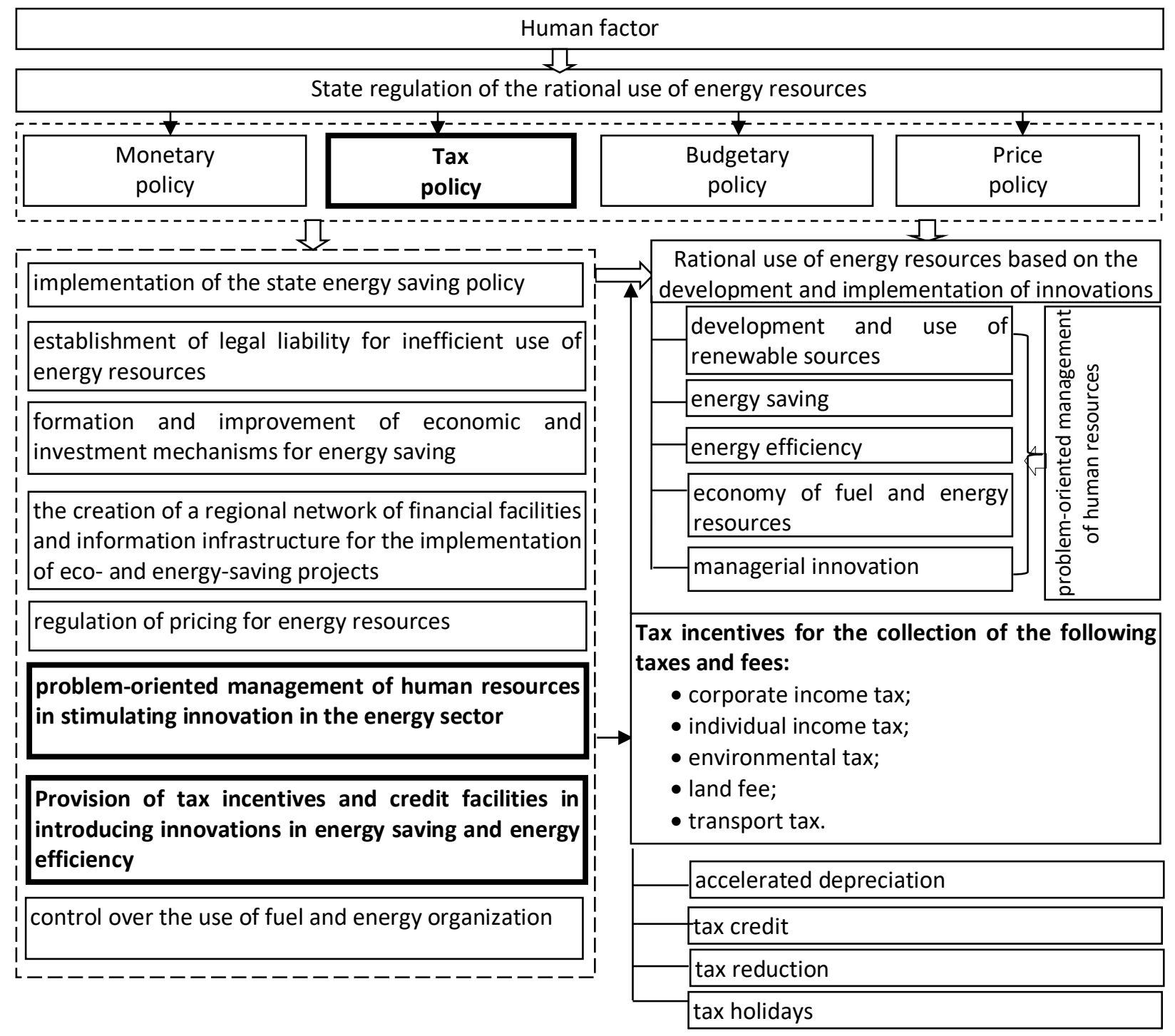

Figure 1. The role of the tax policy and human factor in state regulation of the rational use of energy resources and innovations in the energy sector Source: Author's

The country's energy saving potential lies in [4; 5] increase of its own energy carriers production; reduction of irrational use of energy resources; introduction of new energy-efficient projects and programs at the national 
and regional levels; introduction of resource-saving technologies in all sectors of the economy and the social sphere.

For national economies to achieve sustainable development, efficient use of energy resources is timely and relevant for several reasons:

- economic - this is evidenced by the relatively high energy consumption in the manufacturing sector in developing countries, which makes the cost of products uncompetitive on world markets;

- political - this is manifested in the issues of energy dependence of countries, which, for example, is about $50 \%$ on average in the EU countries (Austria - 64.7\%, Germany - $61.4 \%$, France - $50 \%$, Italy - 18\%, Japan $7 \%$ ) [6; 7];

- environmental - the production of energy resources results in a negative impact on the environment.

Given these reasons, considering today's needs, promoting rational use of energy resources is one of the most important priorities for the country's socio-economic development. To ensure sustainable development of the economy and stimulate the efficient use of energy resources, a set of government regulation measures is used in world practice. Innovative development includes a number of factors that affect the innovation process and effectiveness of innovation, the most important of which is the human factor. Based on a problem-oriented approach to human resource management, the influence of the human factor on innovative development in the energy sector can be divided into a three-level system (Fig.3). This approach involves choosing the methods and tools for human resource management that are most adaptive, flexible and timely for addressing specific problems at the methodological and practical levels.

\begin{tabular}{|c|c|c|c|}
\hline Levels & \multicolumn{2}{|c|}{ Directions and instruments of state support for innovation } & Role of the human factor \\
\hline \multicolumn{3}{|c|}{ 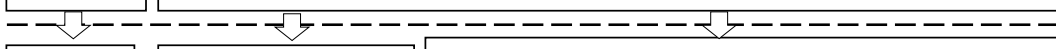 } & $-------\leq 2-----1$ \\
\hline 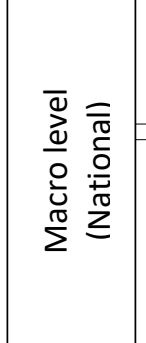 & $\begin{array}{l}\text { legislative, } \\
\text { financial, } \\
\text { institutional, } \\
\text { information } \\
\text { support, etc. }\end{array}$ & $\begin{array}{l}\text { Laws and regulations; innovative target } \\
\text { programs; transfer of knowledge in the } \\
\text { sphere of energy saving and efficiency; } \\
\text { twinning; coordination of interaction of } \\
\text { science, education and business in the } \\
\text { sphere of innovations in the energy } \\
\text { sector, stimulating business to introduce } \\
\text { innovations, etc. }\end{array}$ & $\begin{array}{l}\text { competence of personnel of } \\
\text { public authorities in the } \\
\text { sphere of stimulating } \\
\text { innovative development; } \\
\text { ability to justify the } \\
\text { economic feasibility of } \\
\text { applying instruments to } \\
\text { stimulate innovation }\end{array}$ \\
\hline \multicolumn{4}{|c|}{ 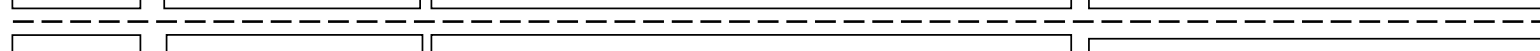 } \\
\hline 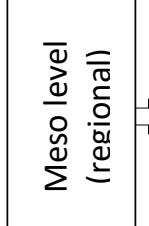 & $\begin{array}{l}\text { Organizational, } \\
\text { information, } \\
\text { infrastructure, } \\
\text { financial } \\
\text { support }\end{array}$ & $\begin{array}{l}\text { effective linkages between the research } \\
\text { sphere and the real economy; regional } \\
\text { competitions of innovative vouchers, } \\
\text { business incubators, technoparks, etc. }\end{array}$ & $\begin{array}{l}\text { competence of personnel of } \\
\text { regional authorities in } \\
\text { developing mechanisms for } \\
\text { stimulating innovation in the } \\
\text { region }\end{array}$ \\
\hline \multicolumn{4}{|c|}{$----ー------------------------------ー---------------$} \\
\hline 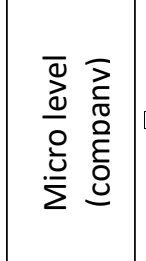 & $\begin{array}{l}\text { staffing; direct } \\
\text { financial } \\
\text { support, } \\
\text { tax support } \\
\text { instrumentss }\end{array}$ & $\begin{array}{l}\text { tax benefits; } \\
\text { staffing for development and innovation; } \\
\text { energy management programs; } \\
\text { outsourcing; } \\
\text { subcontracting }\end{array}$ & $\begin{array}{l}\text { availability of personnel for } \\
\text { developing } \\
\text { implementing innovations } \\
\text { as well as management } \\
\text { personnel for developing } \\
\text { energy management }\end{array}$ \\
\hline
\end{tabular}

Figure 3. The three-level system of problem-oriented management of human resources in stimulating innovation in the energy sector

Source: Author's

At the macro level, for the implementation of regulatory, legal, financial, institutional and other support for innovative development, there is a need for competent personnel that can develop mechanisms for stimulating innovative development in the country; can justify the expediency of using instruments to stimulate innovation; are able to effectively coordinate the cooperation of science, government, education and business to achieve 
the goal. To reach this goal, it is necessary to: conduct training and professional development of state employees; twinning and exchange of experience in organizing state support in the sphere of energy efficiency and renewable energy; provide internships abroad and participation in international programs, grants, etc.

At the meso level, the human factor manifests its duality. On one hand, at the regional level innovative development is influenced by the qualifications and competencies of the personnel of regional authorities. These include those who take part in elaborating regional innovation development programs, the mechanisms for the operation of innovative clusters, technology parks, etc., as well as coordinate interaction between science, educational institutions and business in the preparation and search for specialists in the field of development and implementation of innovations among enterprises. On the other hand, the availability of intellectual and scientific potential in the region determines the directions of its innovative development.

At the micro level, in the context of support for innovation in the energy sector, on the state's part, it is necessary to implement a policy of direct financing and tax incentives for entrepreneurs who through innovation create new job opportunities and attract highly qualified specialists within the sphere of innovation. For example, the experience of the Netherlands in tax incentives for innovation is to provide a $50 \%$ exemption from social contributions to personnel employed in R\&D. In world practice, reduced rates of the single tax and profit tax are applied when using the technology of outsourcing. On the part of the entrepreneur it is important to interact with the authorities and scientific and educational institutions in the implementation of innovative activities; development of managerial innovations in the sphere of human resource management.

\section{Instruments for stimulating innovation and energy efficiency in the energy sector}

Foreign experience shows that under market economy conditions, economic methods of state regulation are preferable, the most effective among which can be employment of the country's tax system. The fact that the tax system plays a significant role in stimulating (or hindering) resource conservation is also noted by S. Aptekar [8] as well as by other scientists.

According to the World Energy Council report [9], which assesses energy efficiency policies in 90 countries worldwide, economically developed countries use fiscal measures more than other countries. In foreign countries, the following fiscal measures are mainly used: tax credits, accelerated depreciation, tax reduction. Tax incentives, as a means of stimulating the efficient use of energy resources, are most widely used in the US, Japan and a number of European countries since the late 70 s to early 80 s after the global energy crisis. It was at that time that the economically developed countries intensified the elaboration of measures to stimulate energy saving. A number of European Union directives that regulated the energy saving process in general and methods to stimulate it were adopted. Among them there can be singled out the Council's recommendation on the rational use of energy in industrial enterprises [10], on the promotion of energy efficiency investments [11], and on the promotion of the use of biofuels and other renewable fuels for transport [12].

The world practice of taxation shows that tax incentives for the efficient use of energy resources can be applied in the collection of such direct taxes and fees such as: corporate income tax; individual income tax; environmental tax; land fee; transport tax. The process of stimulating the efficient use of energy resources in the context of direct taxes and fees occurs through the provision of tax incentives (in some cases subject to certain restrictions) for industrial enterprises and households for the use of energy-efficient and energy-saving technologies and alternative energy sources. The main objectives of this process should be singled out for two groups of subjects: business entities and households (Table 1). 
Table 1. The objectives of applying tax incentives for efficient use of energy resources depending on the subject

\begin{tabular}{|c|c|}
\hline Objectives for business entities & Objectives for households \\
\hline $\begin{array}{l}\text { reducing the amount of corporate income tax by the full amount of } \\
\text { the targeted expenditures incurred, or a part thereof; by the full or } \\
\text { partial amount of the increment of corresponding expenses in the } \\
\text { reporting period in relation to the established base }\end{array}$ & \multirow[t]{2}{*}{$\begin{array}{l}\text { reducing the amount of individual } \\
\text { income tax when using alternative } \\
\text { energy sources or implementing } \\
\text { activities related to energy saving }\end{array}$} \\
\hline $\begin{array}{l}\text { reducing the cost of industrial products through the use of less } \\
\text { energy-intensive production technologies, which will increase the } \\
\text { profit of the enterprise and improve its competitiveness in world } \\
\text { markets }\end{array}$ & \\
\hline $\begin{array}{l}\text { providing fixed assets renovation due to application of accelerated } \\
\text { depreciation. Higher rates and a shorter (compared with the usual } \\
\text { order) depreciation period allow the payer to increase in each tax } \\
\text { period the use of such fixed assets of the amount of accrued } \\
\text { depreciation, reduce the taxed item }\end{array}$ & $\begin{array}{l}\text { reducing government spending on } \\
\text { energy and increasing the country's } \\
\text { energy independence by cutting off } \\
\text { energy consumption by households }\end{array}$ \\
\hline $\begin{array}{l}\text { stimulating the use of environmentally safe technologies of industrial } \\
\text { production, which should allow to reduce harmful emissions into the } \\
\text { atmosphere and discharges into water bodies }\end{array}$ & $\begin{array}{l}\text { reducing harmful emissions into the } \\
\text { atmosphere }\end{array}$ \\
\hline
\end{tabular}

The world practice of stimulating the efficient use of energy resources demonstrates the application of various tax incentives to achieve the goal. Thus, based on the Worldwide tax summaries: Corporate Taxes 2017/18 report (published by PwCIL [13]), the Energy Charter's report "Investments in Energy Efficiency. Elimination of barriers" [14], in the article the application of tax incentives to stimulate the efficient use of energy resources in countries that employ such instruments is systematized (Table 2).

Table 2. Features of using incentives to stimulate the efficient use of energy resources in individual countries when collecting the corporate income tax

\begin{tabular}{|c|c|}
\hline Country & Application features \\
\hline \multicolumn{2}{|r|}{ Accelerated depreciation } \\
\hline Australia & $\begin{array}{l}\text { Accelerated depreciation is available for capital expenses for the exploration of } \\
\text { geothermal energy sources. Such expenses are entitled to immediate } 100 \% \text { write-off } \\
\text { [13]. }\end{array}$ \\
\hline Argentina & $\begin{array}{l}\text { Accelerated depreciation (write-off of expenses within three years) is available for } \\
\text { exploration of alternative energy sources (e.g. wind power) [10]. }\end{array}$ \\
\hline United Kingdom & $\begin{array}{l}\text { The opportunity to write off up to } 100 \% \text { of the cost of the relevant technologies and } \\
\text { equipment within a year from the date of acquisition [15]. The right to accelerated } \\
\text { depreciation is available only for products that are included in the Energy Technology } \\
\text { List, the criteria for which are reviewed and approved annually, taking into account the } \\
\text { latest developments [16]. The List itself [17] is updated monthly and contains a detailed } \\
\text { list of products specifying the manufacturer and model numbers. } \\
\text { There are also four categories of products not included in the list of energy } \\
\text { technologies, but are entitled to accelerated depreciation (non-listed products): } \\
\text { equipment based on the use of automatic control and orientation, which is specifically } \\
\text { designed for measuring and analyzing data on energy consumption; equipment for } \\
\text { combined heat and power generation (cogeneration) high-efficiency light modules; } \\
\text { insulation of pipelines [11]. }\end{array}$ \\
\hline Ireland & $\begin{array}{l}\text { Accelerated depreciation of } 100 \% \text { in the first year is provided for expenses for some } \\
\text { energy-saving equipment. The following categories of equipment are entitled to } \\
\text { accelerated depreciation: related to information and communication technologies; } \\
\text { related to provision of heat and energy supply; electric cars and vehicles using } \\
\text { alternative fuel systems; heating, ventilation and air conditioning, lighting systems; } \\
\text { motors and drives; energy management systems of buildings; freezing and cooling } \\
\text { systems; electro-mechanical systems; equipment of restaurants and hotels [18]. }\end{array}$ \\
\hline
\end{tabular}




\begin{tabular}{|c|c|}
\hline Country & Application features \\
\hline Liechtenstein & $\begin{array}{l}\text { Energy-saving equipment and systems using solar energy are depreciated at a rate of } \\
50 \%[5] \text {. }\end{array}$ \\
\hline Luxembourg & $\begin{array}{l}\text { Special accelerated depreciation of } 80 \% \text { of the value of fixed assets is available for } \\
\text { assets that contribute to energy savings [13]. }\end{array}$ \\
\hline Singapore & $\begin{array}{l}\text { Amortization deductions of } 100 \% \text { are available for capital expenses for energy-saving } \\
\text { equipment [13]. }\end{array}$ \\
\hline \multicolumn{2}{|r|}{ Tax credit } \\
\hline USA & $\begin{array}{l}\text { The tax credit is established at the federal level in the amount of up to USD 2,000 for } \\
\text { all new energy-efficient houses. This benefit can be applied by home producers if } \\
\text { energy consumption is } 50 \% \text { less compared to the requirements envisaged by the } \\
\text { International Energy Conservation Code (IECC). A USD 1,000 tax credit is provided for } \\
\text { homes that consume energy } 30 \% \text { less than the requirements set by the IECC. } \\
\text { A } 30 \% \text { Manufacturing Tax Credit is applied for investment in new, expanded or refined } \\
\text { prospective energy projects in production. Applicants received tax incentives, } \\
\text { depending on the expected commercial viability of the project and the ranking of their } \\
\text { project compared to other projects [18]. }\end{array}$ \\
\hline PRC & $\begin{array}{l}\text { Enterprises that buy and use specified by the state equipment that is intended for } \\
\text { energy saving have the right to a tax credit of } 10 \% \text { of the investments in such } \\
\text { equipment. Any unused amount can be transferred and accounted for in the following } \\
\text { five years [13]. }\end{array}$ \\
\hline Luxembourg & $\begin{array}{l}\text { A complementary tax credit is granted in the amount of } 12 \% \text { of the increase in } \\
\text { investments in tangible assets during the tax year. Regardless of this, the company can } \\
\text { receive a tax credit of } 8 \% \text { on the first EUR } 150,000 \text { of new investments in tangible } \\
\text { energy-saving assets, which are depreciated, and } 4 \% \text { on the amount of the } \\
\text { corresponding investment exceeding EUR } 150,000 \text { [20]. }\end{array}$ \\
\hline Spain & $\begin{array}{l}\text { Companies are entitled to a } 30 \% \text { tax credit on investments in equipment to preserve } \\
\text { and improve the environment and conserve energy. Equipment that qualifies for a tax } \\
\text { credit is listed in the Basque List of Environmental Technologies [20]. }\end{array}$ \\
\hline Hungary & A tax credit is granted in the amount up to $80 \%$ of the tax payable [20]. \\
\hline \multicolumn{2}{|r|}{ Tax reduction } \\
\hline USA & $\begin{array}{l}\text { The Energy Efficient Commercial Buildings Tax Deduction [21] is applied at a rate of USD } \\
0.30-1.80 \text { per square foot }\left(0.093 \mathrm{~m}^{2}\right) \text {, depending on the technology and the degree of } \\
\text { energy reduction. }\end{array}$ \\
\hline Australia & $\begin{array}{l}\text { A tax discount of } 150 \% \text { of the actual cost of energy audits, not exceeding BBD } 25,000 \\
\text { (USD } 12,500 \text { ) is provided for each year within five years, and additional write-off of } 50 \% \\
\text { of the cost of improvement of premises or installing systems for generating electricity } \\
\text { from renewable sources. The condition for obtaining a discount is the absence of debts } \\
\text { for the payment of the profit tax, VAT, land tax, and national insurance premiums [13]. }\end{array}$ \\
\hline Belgium & $\begin{array}{l}\text { Enterprises that implement energy-saving investments can claim a tax discount of } \\
14.5 \% \text { of the amount of qualifying investments. In case of insufficiency or absence of } \\
\text { taxable profit, investment deductions can be transferred without any restrictions in } \\
\text { time or amount [15]. }\end{array}$ \\
\hline Netherlands & $\begin{array}{l}\text { For investments in energy efficient assets, a tax discount of } 41.5 \% \text { of the total annual } \\
\text { amount of investments exceeding EUR } 2,300 \text { is foreseen [15]. }\end{array}$ \\
\hline \multicolumn{2}{|r|}{ Tax holidays } \\
\hline Fiji & $\begin{array}{l}\text { The income received by the taxpayer from a new type of activity for the processing of } \\
\text { agricultural raw materials in biofuel can be exempted from the profit tax for a period } \\
\text { of ten years. Exemption from the income tax for five years may be available to } \\
\text { a taxpayer who participates in renewable energy and cogeneration projects [13]. }\end{array}$ \\
\hline Honduras & $\begin{array}{l}\text { Renewable energy producers have the right to a tax holiday on corporate income tax } \\
\text { for five years [22]. }\end{array}$ \\
\hline Indonesia & $\begin{array}{l}\text { Industrial enterprises in the sphere of renewable energy have the right to exemption } \\
\text { from corporate income tax for a period of five to ten years from the commencement } \\
\text { of industrial activity, after which it is possible to reduce tax liabilities by } 50 \% \text { for another } \\
2 \text { years [21]. }\end{array}$ \\
\hline
\end{tabular}


Continuation of Table 2

\begin{tabular}{|l|l|}
\hline Country & Application features \\
\hline Malaysia & $\begin{array}{l}\text { Upon applications granted before 31 December 2015, full exemption from the income } \\
\text { tax for ten years is given to companies engaged in the production of energy from } \\
\text { renewable sources (biomass energy, hydro-energy, or solar energy), and energy service } \\
\text { companies [13]. }\end{array}$ \\
\hline Sri Lanka & $\begin{array}{l}\text { From } 1 \text { April 2013, a ten-year tax exemption for the profits and incomes of enterprises } \\
\text { from the cultivation of renewable energy crops on agricultural lands is provided [15]. }\end{array}$
\end{tabular}

Source: $[7 ; 10 ; 11 ; 13 ; 15 ; 16 ; 17 ; 18 ; 20 ; 21 ; 22]$

According to Table 2 and 3, the most widespread instrument/incentive/measure for stimulating energy efficiency in industry in the world practice is accelerated depreciation (about 60\%) and a tax credit (about 40\%). At the same time, the main rate of accelerated depreciation in most countries is $100 \%$, which allows taxpayers to reduce the taxed item by the entire amount of certain capital expenses in the first year. Also, rates of $80 \%, 50 \%$ and $33.3 \%$ are applied, i.e., the maximum period during which certain capital expenses reduce the taxed item is 3 years.

The practice of applying a tax credit testifies to the amount of the loan from $4 \%$ to $100 \%$ of the corresponding expenses. The possibility of reducing tax liabilities without the need to pay them in the future makes the tax credit attractive to taxpayers, as evidenced by statistics on the application of a tax credit by sector: industry $32 \%$, households $-36 \%$ [19].

Table 3. Applying tax incentives to stimulate the efficient use of energy resources in certain countries when collecting corporate income tax

\begin{tabular}{|c|c|c|c|c|}
\hline Countries & $\begin{array}{l}\text { accelerated } \\
\text { depreciation }\end{array}$ & $\begin{array}{l}\text { tax } \\
\text { credit }\end{array}$ & $\begin{array}{l}\text { tax } \\
\text { holidays }\end{array}$ & $\begin{array}{l}\text { tax } \\
\text { reduction }\end{array}$ \\
\hline Australia & + & & & + \\
\hline Argentina & + & & & \\
\hline Belgium & & & & + \\
\hline United Kingdom & + & & & \\
\hline \multicolumn{5}{|l|}{ Hungary } \\
\hline Honduras & & & + & \\
\hline Indonesia & & & + & \\
\hline Ireland & + & & & \\
\hline Spain & & + & & \\
\hline PRC & & + & & \\
\hline Liechtenstein & + & & & \\
\hline Luxembourg & + & + & & \\
\hline Malaysia & & & + & \\
\hline Netherlands & + & & & + \\
\hline South Africa & & & & + \\
\hline Russia & + & & & \\
\hline Singapore & + & & & \\
\hline USA & & + & & + \\
\hline Uruguay & & & + & \\
\hline Fiji & & & + & \\
\hline Sri Lanka & & & + & \\
\hline
\end{tabular}

Source: $[7 ; 10 ; 11 ; 13 ; 15 ; 16 ; 17 ; 18 ; 20 ; 21 ; 22]$

A tax reduction is mainly popular in developed countries and is used in the USA, Australia, Belgium, South Africa and the Netherlands. Quite often, a tax reduction includes not all relevant expenses but only a certain percentage, or there is a restriction in the form of a certain amount of expenses. 
Tax holidays are seldom used for stimulating the implementation of energy efficient equipment and increasing the energy efficiency of production in economically developed countries. They are applied in China, Fiji, Honduras, Indonesia, Malaysia, Sri Lanka and Uruguay. Most often, tax holidays are granted for a period of 3 to 10 years in the amount of $40 \%$ to $100 \%$ of tax liabilities.

Among instruments of tax regulation of the rational consumption of energy resources for individual taxes and fees there are:

- instruments using the value added tax (differentiated VAT rates, increase of the VAT rate for traditional fuel and energy resources, VAT exemption, reduction of the VAT rate). Thus, for example, the average value of the base VAT rate in EU countries is $21.3 \%$, and the average level of the reduced VAT rate is $6.4 \%$;

- instruments using the excise tax (increase of the excise tax rate for traditional fuel and energy resources, excise tax exemption for biofuels and bioethanol, reduction of the excise tax rate for biofuels and bioethanol). Thus, in Great Britain the share of taxes in the price for fuel (the excise tax and VAT) reaches 55\%, which is much higher than that in the USA. A zero rate for electricity is a powerful incentive for the production and use of electric vehicles. In Germany, the excises for motor fuel provide about $10 \%$ of tax revenues to the federal budget;

- instruments using the duty (exemption from / reduction of the import duties for equipment and materials that contribute to rationalizing the consumption of fuel and energy resources);

- instruments using the environmental tax (expansion of the circle of environmental taxpayers, reduction of rates / exemption from the environmental tax for payers introducing technologies or processes that facilitate rationalizing the consumption of fuel and energy resources, increase of environmental tax rates on actual emissions to air);

- instruments using land fees (land tax credit, increase of tax (reporting) period, tax holidays, deferment or payment in installments of tax obligations on land fees for individuals carrying out activities that promote rationalizing the consumption of fuel and energy resources).

- instruments using the personal income tax (a tax credit, tax reduction, tax holidays for the personal income tax on the implementation of activities that promote rationalizing the consumption of fuel and energy resources, deferment and payment in installments of tax obligations for those introducing more advanced technologies or processes).

Consequently, there is a sufficient number of tax incentives for the efficient use of energy resources, the implementation of which would allow rationalizing the consumption of fuel and energy resources.

\section{Summary and conclusions}

The systematization of the world experience in the sphere of using tax incentives for energy efficiency and the application of a systematic approach to the problems of tax regulation of rational energy consumption have made it possible to identify directions, the simultaneous use of which will contribute to the formation of additional financial benefits. These directions include:

- stimulating rational consumption of energy resources;

- encouraging rational consumption of energy by business entities (legal entities), individuals (private households);

- promoting R \& D in the sphere of rationalization of energy consumption;

- stimulating production of goods (equipment, materials, etc.) and services, the use of which will allow rationalizing the consumption of energy resources;

- stimulating production of energy resources from renewable sources;

- stimulating attraction of highly qualified specialists in the field of development and implementation of innovations in the energy sector (for example, the use of reduced rates for social contributions, the stimulation of employment).

To promote rational consumption of energy resources, it is possible to use the majority of existing taxes and fees and such instruments of tax regulation such as changes in tax rates, tax exemption, reduction of the taxed item, spending restrictions, tax credits, accelerated depreciation, tax reduction, deferment or payment in installments, tax holidays, etc. 


\section{Acknowledgements}

This research was part of the research theme "Theoretical and methodological substantiation of directions for overcoming the structural deformation of the country's industrial complex on the basis of its innovation and technological modernization" (2017-2019), financed by the National Academy of Sciences of Ukraine.

\section{References}

[1] O.M.Sukhodolia, Energy efficiency of the economy in the context of national security: research methodology and implementation mechanism, NASU, Kiev, 2006.

[2] G.O. Dzyana, R.B. Dzyaniy, Socio-ecological aspects of realization of state policy in the sphere of energy saving of Ukraine, LRIPA NADM, Lviv, 2010.

[3] D.YU. Drozhzhin, (2015) State regulation of energy efficiency in the industry of 1(36) (2015) 195-200.

[4] P.D. Nemish, (2013) The essence, estimation and directions of increase of efficiency of the mechanism of energy saving of agrarian and industrial complex, Innovative economy. Vol. 73(45) (2013) 46-53.

[5] YU. B. Ivanov, O. S. Vinnikova, Taxes and rational energy consumption: realities and prospects, KUZNETS KhNUE, Kharkiv, 2014.

[6] Statistican Yearbook of World Energy 2017. Access mode : https://yearbook.enerdata.ru/totalenergy/world-energy-intensity-gdp-data.html

[7] Energy strategy of Ukraine for the period up to 2030 Access mode: http://zakon4.rada.gov.ua/laws/show/145\%D0\%B0-2006-\%D1\%80.

[8] S.S. Aptekar', (2006) The role of taxation in the implementation of resource-saving measures in metallurgy (Bulletin of the M. Tugan-Baranovsky Donetsk State University of Economics and Trade), 4, Vol. 2 (2006) 88-97.

[9] Energy Efficiency: A Recipe for Success http://www.worldenergy.org/documents/fdeneff_v2.pdf.

[10] http://www.is.svitonline.com/sukhodolya/es/law/25_Oct_rational_use.htm.

[11] http://www.is.svitonline.com/sukhodolya/es/law/382X0604_investment_rational_use.htm.

[12] Directive 2003/30/EC of the European Parliament and of the Council of 8 May 2003 on the promotion of the use of biofuels or other renewable fuels for transport (Official Journal L 123, 17/05/2003 P. 0042 0046) http://www.is.svitonline.com/sukhodolya/es/law/ promotionbiofuels.htm.

[13] Worldwide Tax Summaries Corporate Taxes 2017/18. Access mode : https://www.pwc.com/gx/en/tax/corporate-tax/worldwide-tax-summaries/pwc-worldwide-taxsummaries-corporate-taxes-2017-18.pdf

[14] Energy Charter. Access mode : https://energycharter.org/

[15] First year allowances for energy saving products [Access mode : http://www.hmrc.gov.uk/capitalallowances/fya/energy.htm.

[16] Energy Technology List Access mode: https://etl.beis.gov.uk/engetl/fox/live/ETL_PUBLIC_PRODUCT_SEARCH

[17] Find ETL Products. Access mode : https://www.gov.uk/government/publications/products-removedfrom-the-energy-technology-product-list-etpl

[18] Energy Efficiency: A Recipe for Success. Access mode : https://www.worldenergy.org/wpcontent/uploads/2012/10/PUB_Energy_Efficiency_-A_Recipe_For_Success_2010_WEC.pdf

[19] Fact sheet: 48c manufacturing tax credits Access mode : http://energy.gov/downloads/fact-sheet-48cmanufacturing-tax-credits.

[20] Tax credit for energy transition (CITE) / Site of International Energy Agency. Access mode: https://www.iea.org/policiesandmeasures/pams/france/name-22732-en.php.

[21] Energy-Efficient Commercial Buildings Tax Deduction. Access mode: http://www.dsireusa.org/incentives/incentive.cfm?Incentive_Code=US40F\&re=0\&ee=1.

[22] Renewable energy in $\quad$ Honduras. Access
http://en.wikipedia.org/wiki/Renewable energy in Honduras\#cite ref-WB07 1-3.

[21] J. Maio, J. Maio, S. Zinetti, R. Janssen, Energy efficiency policies in buildings - the use of financial instruments at member state level. Access mode: http://renovate-europe.eu/wpcontent/uploads/2015/09/BPIE_Financial_Instruments_08-2012.pdf. 